Elżbieta Laskowska

Uniwersytet Kazimierza Wielkiego

w Bydgoszczy

elaskows@ukw.edu.pl
Data przesłania tekstu do redakcji: 04.02.2015

Data przyjęcia tekstu do druku: 05.03.2015

\title{
Emocje w dyskursie publicznym
}

\begin{abstract}
Laskowska Elżbieta, Emocje w dyskursie publicznym (Emotions in Public Discourse). "Poznańskie Studia Slawistyczne" 9. Poznań 2015. Publishing House of the Poznań Society for the Advancement of the Arts and Sciences, pp. 51-63. ISSN 2084-3011.

In political discourse, the recipient is collective and intentional. Being a part of public discourse, political discourse abounds in speech acts that have emotive-evaluative function. In the present paper, the Author discusses the most frequent evaluative-emotive acts gleaned from parliamentary speeches, and these include: accusations, complaining, bragging, expressing recognition and justification. The methodological framework adopted by the Author adheres to the model proposed by Aleksy Awdiejew. Another phenomenon observable in public discourse is aggression. Irrespective of this, expressing emotions in public discourse is sometimes ideologically motivated.
\end{abstract}

KEYwORDS: public discourse; politics; evaluative-emotive speech acts; aggression; ideology

\section{Dyskurs publiczny}

W poszukiwaniu odpowiedzi na pytanie o różnicę między dyskursem publicznym a niepublicznym można brać pod uwagę następujące czynniki: temat wypowiedzi, cel wypowiedzi, sposób ukształtowania wypowiedzi, gatunek tekstu, składniki sytuacji komunikacyjnej, w tym typ nadawcy, typ odbiorcy, typ kontaktu, tworzywo, okoliczności fizyczne (Laskowska 2004:14). Jak jednak wskazuje obserwacja wypowiedzi, czynniki te nie do końca są w stanie jasno określić granicę między komunikowaniem publicznym a niepublicznym. Na przykład tradycyjnie dla komunikowania publicznego charakterystyczna była tematyka związana z życiem zbiorowym, a dla niepublicznego - z życiem osobistym. Współcześnie w mediach, a więc w komunikowaniu publicznym, mówi się niekiedy o sprawach bardzo osobistych (np. telewizyjne programy talk-show), a w domach i wśród przyjaciół często dyskutujemy na temat życia zbiorowego. Innym przejawem zacierania się granic między komunikowaniem publicznym 
a niepublicznym jest przenikanie potoczności do języka mediów, a nawet wulgaryzacja tego języka. Dlatego przyjmuję, że dla komunikowania publicznego charakterystyczny jest odbiorca zbiorowy i zamierzony (Laskowska 2009b: 55). Jeśli zdarzy się, że uczestnicy dyskursu porozumiewają się ze sobą niepublicznie, a ich wypowiedzi zyskują w sposób niezamierzony odbiorcę publicznego, to wtedy mówimy o dyskursie upublicznionym ${ }^{1}$. Dyskurs taki zachodzi wtedy, kiedy np. rozmówcy nie mają świadomości, że są nagrywani. Mamy wówczas do czynienia z podwójnym odbiorcą: odbiorcą indywidualnym jest uczestnik dyskursu zamierzonego jako niepubliczny, odbiorcą zbiorowym są wszyscy ci, którzy upublicznione wypowiedzi odbierają ${ }^{2}$.

Czy należałoby utożsamiać określenia komunikowanie publiczne i komunikowanie polityczne? Komunikowanie polityczne bywa rozumiane jako proces ,pośredniczenia w relacjach między instytucjami rządzącymi i wyborcami” (Dobek-Ostrowska 2006: 134). We współczesnej refleksji nad komunikowaniem politycznym badacze podkreślają jego dwukierunkowość (Dobek-Ostrowska 2006:134). Aby jednak odpowiedzieć na pytanie o różnice lub brak różnic między komunikowaniem publicznym a politycznym, trzeba przyjąć, czym jest polityka. Cetwiński i Karwat (2001: 17) definiują politykę jako dziedzinę polegającą na regulowaniu życia społecznego. Nie do końca przekonujące jest jednak sformułowanie ,życie społeczne”. Dla naszych potrzeb lepsze będzie określenie życie publiczne. Należałoby się mimo to zastanowić, gdzie są granice polityki. Czy wszędzie tam, gdzie jest władza, jest i polityka? Nie, bo przykładowo władza rodzicielska nie ma nic wspólnego z polityką. Czy władza w instytucji ma charakter polityczny? Nie każda instytucja mieści się w pojęciu polityki. Na przykład dyrektor szkoły czy szef firmy z powodu samego faktu bycia szefem nie jest politykiem. Władzą jest samorząd terytorialny. Ktoś, kto w tej władzy uczestniczy, bywa nazywany lokalnym politykiem. I w tym miejscu możemy już mówić o najmniejszym wymiarze polityki. Większy wymiar wiąże się z władzą państwo-

${ }^{1}$ Do takiego wniosku doszłam podczas dyskusji na spotkaniu naukowym w Łodzi w marcu 2008 roku. Spotkanie odbyło się w ramach konferencji „Rozmowy o komunikacji”.

${ }^{2}$ Przy wskazanych założeniach dyskurs potoczny ma odbiorcę pojedynczego i kameralnego, odbiorca może być zamierzony i niezamierzony. 
wą, a jeszcze większy - z władzą w przedstawicielstwach społeczności ponadpaństwowych.

Słowo polityka używane jest w co najmniej trzech znaczeniach: 1) uczestnictwo w strukturach władzy lub zmierzanie do niego, 2) wypowiadanie się publiczne na temat organizacji życia zbiorowego, 3) sprzyjanie określonemu ugrupowaniu politycznemu. Politykę w pierwszym znaczeniu uprawiają ci, którzy sprawują władzę państwową lub samorządową bądź dążą do osiągnięcia władzy. Drugie znaczenie omawianego leksemu przywoływane jest zarówno przez wypowiedzi na temat życia zbiorowego, jak i działania mające na to życie wpływ, np. udział w wyborach. Trzecie znaczenie pojęcia polityki aktualizuje się wtedy, kiedy ktoś manifestuje punkt widzenia właściwy dla jakiejś opcji politycznej ${ }^{3}$. Warto zwrócić uwagę na fakt, że ostatnie z omawianych znaczeń może pojawić się w kontekście, który nadaje mu negatywne nacechowanie wartościujące. Na przykład:

To była decyzja polityczna, a nie merytoryczna.

Tak wypowiedział się jeden z radnych podczas obrad Rady Miejskiej Bydgoszczy (w grudniu 1993 roku). Do wypowiedzi skłonił go fakt następujący: pewien projekt uchwały był opiniowany najpierw przez przedstawicieli poszczególnych komisji, a później przez przedstawicieli klubów. Wszystkie opinie komisji były pozytywne, choć w wypowiedziach zwracano uwagę na pewne braki projektu, a opinie większości klubów były negatywne (wskazywano w nich na braki jako przesłanki do negatywnych opinii) ${ }^{4}$. Słowo „polityczny” w przedstawionym kontekście określa powiązanie z określoną partią polityczną. Współcześnie często się zdarza uczestnikom dyskursu publicznego używać słowa „polityka” i pokrewnych w najwęższym ze wskazanych znaczeń.

${ }^{3}$ Kiedy byłam członkiem Rady Miejskiej Bydgoszczy (w latach 1990-1994), jeden z kolegów radnych poprosił mnie o rozmowę i powiedział, że będzie ona miała charakter polityczny. Podczas rozmowy otrzymałam propozycję wstąpienia do powstającego klubu radnych (klub nosił nazwę tożsamą z nazwą jednej z ówcześnie istniejących partii politycznych).

${ }^{4} \mathrm{~W}$ obu gremiach (komisjach i klubach) uczestniczyły te same osoby. Ostatecznie Rada Miejska odrzuciła większością głosów projekt uchwały, co przez jednego z radnych zostało skomentowane w przytoczonym cytacie. 
Niezależnie jednak od tego, w jaki sposób precyzujemy pojęcie, przyjąć należałoby, że komunikowanie polityczne wchodzi w skład komunikowania publicznego. Poza obszarem komunikowania politycznego pozostają m.in. dyskurs dydaktyczny, dyskurs duszpasterski ${ }^{5}$, wiele dyskursów w obrębie dyskursu medialnego, np. recenzje dzieł sztuki, wywiady ze sportowcami, programy kulinarne itd.

Irena Kamińska-Szmaj, pisząc o komunikowaniu politycznym w XX wieku, wykorzystuje następującą definicję komunikowania politycznego:

Komunikacja polityczna to przestrzeń, w której spotykają się różnorodne poglądy i stanowiska trzech grup aktorów, którzy mają prawo wypowiadać się publicznie w kwestiach politycznych. Aktorami tymi są politycy z jednej i opinia publiczna z drugiej strony. Między nimi sytuuje się trzecia grupa, czyli dziennikarze (Kamińska-Szmaj 2007: 11).

Warto zauważyć, że takie określenie komunikowania politycznego może odnosić się wyłącznie do społeczeństw demokratycznych.

Bogdan Walczak określa język polityki jako:

funkcjonalną odmianę języka ogólnego (prymarnie w jego wariancie oficjalnym), stosowaną w tekstach, które: 1) są wytwarzane przez środowisko polityków i ludzi z nimi związanych (doradców, rzeczników prasowych, pozostających na usługach specjalistów z dziedziny socjotechniki, propagandy, reklamy itp.) oraz dziennikarzy specjalizujących się w problematyce politycznej, 2) są adresowane intencjonalnie do wszystkich użytkowników języka ogólnego, 3) dotyczą sfery polityki i 4) odznaczają się dominacją funkcji perswazyjnej (przy obecności - w różnych tekstach tej odmiany w bardzo różnym stopniu, w tym również zerowym - także innych funkcji, takich jak informacyjna, ekspresywna czy autoteliczna) (Walczak 1994: 20).

Autor wskazuje na cztery cechy języka polityki: typ nadawcy, typ odbiorcy, temat, funkcję. Na tym tle warto wspomnieć, że język polityki (język mediów zresztą także) należy do odmiany publicznej, dla której charakterystyczne jest to, że ma odbiorcę zbiorowego i zamierzonego. Tak więc język polityki ma specyficznego nadawcę, ale odbiorcą może być każdy, tematem jest polityka, a funkcją dominującą - perswazja.

${ }^{5} \mathrm{~W}$ dyskursach tych mogą pojawić się odwołania do sytuacji politycznej, w tym jej ocena. Cel wymienionych dyskursów jest jednak inny niż cel dyskursu politycznego. 


\section{Funkcja wartościująco-emotywna wypowiedzi}

Przyjmuję istnienie trzech podstawowych funkcji wypowiedzi: informacyjno-weryfikacyjnej, wartościująco-emotywnej oraz działania (Laskowska 2004: 35 i nn.). W tym miejscu zajmę się funkcją wartościująco-emotywną, przyjmując następujące założenia:

- wyrażanie emocji jest zawsze wartościowaniem;

- wartościując, wyrażamy przekonania wartościujące oraz emocje;

- przekonania wartościujące odnoszą obiekt do normy aksjologicznej, wyrażanie emocji nie musi przywoływać normy, w opisie aktów wartościująco-emotywnych nie dzielę tychże aktów według odnoszenia lub nieodnoszenia się do normy;

- każde wartościowanie (a zarazem wyrażanie emocji) jest perswazyjne;

- w dyskursie publicznym funkcja wartościująco-emotywna występuje bardzo wyraźnie.

Dla opisu aktów wartościująco-emotywnych przyjmuję koncepcję metodologiczną Aleksego Awdiejewa (2004: 123 i nn.). W wypowiedziach o funkcji wartościująco-emotywnej wyróżniam zatem:

- kauzatora, czyli przyczynę stanu powodującą emocje;

- osobę, której wymieniony stan dotyczy;

- korzystność lub niekorzystność omawianego stanu;

- pozytywny lub negatywny znak emocji;

- izomorficzność lub nieizomorficzność oceny stanu (korzystnego lub niekorzystnego) i znaku emocji.

Kauzatorem stanu wywołującego emocje może być nadawca (JA) lub odbiorca (TY) wypowiedzi. Może to być też stan niezależny od żadnego z nich. W tym wypadku przyczyną stanu powodująco emocje może być czynnik niezależny od nikogo $(\mathrm{N})$, ale może to też być osoba trzecia (ON). Stan wywołujący emocje dotyczy nadawcy (JA) lub odbiorcy (TY), osobą tą może też być osoba trzecia $(\mathrm{ON})$; w dyskursie potocznym jest ona zwykle związana albo z nadawcą, albo z odbiorcą, w dyskursie publicznym jest to często zbiorowy podmiot. Stan może być korzystny lub niekorzystny. Korzystność stanu może wywoływać pozytywne emocje, a niekorzystność - negatywne. W takim wypadku powstają izomorficzne akty mowy. Jeśli nadawca ocenia stan jako korzystny, a przy tym wyraża emocje negatywne albo ocenia stan jako niekorzystny i równocześnie 
wyraża emocje pozytywne, wtedy powstają nieizomorficzne akty mowy. Wziąwszy pod uwagę kauzatora (osobę, której stan wywołujący emocję dotyczy), ocenę stanu jako korzystnego lub niekorzystnego oraz znak emocji, można wyróżnić 24 lub 36 typów wartościująco-emotywnych aktów mowy ${ }^{6}$. Materiał zebrany z języka potocznego pozwolił na podanie przykładów wszystkich wyróżnionych aktów mowy (Laskowska 2009a: 351). Badania nad wypowiedziami parlamentarnymi wskazały na niewystępowanie niektórych aktów mowy w tekstach wygłaszanych podczas obrad sejmu i senatu (Laskowska 2004: 140 i nn.).

Analiza wypowiedzi parlamentarnych niech będzie podstawą do wskazania typów wartościująco-emotywnych aktów mowy najczęściej występujących w wypowiedziach publicznych. Nie wszystkie wartościująco-emotywne akty mowy - typologizowane w opisywany tu sposób - mają swoje nazwy w języku ogólnym, dlatego w dalszym ciągu będę się posługiwać następującym modelem: „wyrażanie pozytywnego/negatywnego uczucia z powodu stanu wywołanego przez JA/TY/N korzystnego/niekorzystnego dla JA/TY”. Na przykład:

Odnosimy wrażenie, że pan minister, zdaje się w ogóle nie dostrzegł dorobku ustrojowego III Rzeczypospolitej. Swe działania prowadzi w przekonaniu, że jest jedyną władzą publiczną. Ignoruje istnienie samorządów terytorialnych, korporacji i związków zawodowych $(4 \mathrm{sj}, 21,2 \mathrm{~K})^{7}$.

Wypowiedź realizuje następujący model: „wyrażam negatywne uczucie z powodu stanu wywołanego przez TY, niekorzystnego dla JA" ${ }^{\text {. }}$ W języku ogólnym ten sposób wyrażania emocji nazywamy zarzutem lub pretensją. W wypowiedziach parlamentarnych zarzutów było najwięcej (50\% wszystkich aktów mowy uznanych za wartościująco-emotywne) (Laskowska 2004: 145). Na drugim miejscu (20\%) znalazły się akty skar-

${ }^{6} \mathrm{~W}$ pracy A. Awdiejewa (2004: 124 i nn.) jest 36 typów, w mojej pracy (Laskowska 2004: 141 i nn.) liczba ta wynosi 24. Różnica bierze się z tego, że A. Awdiejew uwzględnił wśród osób, których stan dotyczy, osobę trzecią, w mojej pracy brane są pod uwagę tylko nadawca i odbiorca (inne osoby zostały potraktowane jako bliskie nadawcy lub odbiorcy).

${ }^{7}$ Elementy w poszczególnych skrótach oznaczają kolejno: numer kadencji, sj - Sejm / sn -Senat, numer posiedzenia, dzień obrad, inicjał nazwiska mówcy.

${ }^{8}$ Nadawca wypowiada się w imieniu społeczeństwa, którego jest częścią. Można by tu mówić nie o JA, ale MY (cf. Laskowska 2004: 133 i nn.). 
żenia się, realizujące model: „wyrażam negatywne uczucie z powodu stanu wywołanego przez N, niekorzystnego dla JA”, np.:

To (warunki atmosferyczne - przyp. aut.) jest także przyczyna kryzysu, który dla wszystkich jest bardzo dolegliwy (4sj, 33, 1K).

Kolejne miejsce zajął akt mowy, który można nazwać przechwałką, realizującą model: „wyrażam pozytywne uczucie z powodu stanu wywołanego przez JA, korzystnego dla TY”, np.:

Podjęliśmy w tym tygodniu trudne, ale i twórcze, naszym zdaniem, rozmowy ze związkowcami (4sj, 37, 4P).

Ze względu na liczebność zwracają uwagę ponadto akty mowy wyrażające uznanie (8\%): ,wyrażam pozytywne uczucie z powodu stanu wywołanego przez TY, korzystnego dla JA", np.:

Z zadowoleniem przyjąłem ostatnią inicjatywę ministra pracy i polityki społecznej opracowania rządowych projektów zwalczania społecznego odrzucenia $(4 \mathrm{sj}, 23,2 \mathrm{Z})$.

Około 5\% wartościująco-emotywnych aktów mowy wśród wypowiedzi parlamentarnych stanowią usprawiedliwienia: „wyrażam pozytywne uczucie z powodu stanu wywołanego przez JA, niekorzystnego dla TY", np.:

Chciałabym przeprosić za pytanie, które zadam. Ale w tym momencie jest pani osobą publiczną, więc zapytam: czy pani jest mężatką? (4sn, 71, 2P).

Wymienionych pięć typów wartościująco-emotywnych aktów mowy składa się na statystycznie istotny udział emocji w języku parlamentu. Poza nimi pojawiło się jeszcze osiem (spośród 24 odnalezionych w języku potocznym - Laskowska 2009a: 351), ale obejmują one nikłą część materiału.

Przedstawione typy aktów mowy pochodzą z lat 1997-2003 i reprezentują tylko jeden rodzaj wypowiedzi publicznych. Być może wypowiedzi publiczne, zbierane w innym czasie, pokazywałyby nowe sposoby wyrażania emocji. 


\section{Język agresji a język ideologii}

Badacze języka polityki zwracają uwagę na obecność w nim agresji. Nie jest to zjawisko nowe. Maria Peisert (2004) opisuje przejawy agresji w tekstach dawnych oraz współczesnych, natomiast Irena Kamińska-Szmaj (1994) w wypowiedziach politycznych okresu międzywojennego. Jerzy Bralczyk jedną ze swoich prac poświęca brutalizacji języka publicznego. Autor pisze:

Retoryka brutalności miewa swoje serio przytaczane uzasadnienia - brutalność jest swoistą wartością jako z jednej strony alternatywa dla obłudy, z drugiej jako metoda gwarantująca skuteczność także w działaniach uznawanych za słuszne. Z trzeciej wreszcie strony jako pewien atrybut mocnego człowieka, zwłaszcza mężczyzny przez brutalność pociągającego, fascynującego (Bralczyk 2008: 59).

We współczesnej polszczyźnie także słowo „agresywny” odnosi się do działań mocnych i skutecznych. Z rozważań tych wynika, że agresywność nie jest jednoznacznie oceniana negatywnie. Warto jednak pamiętać, że agresja służy często deprecjonowaniu rozmówcy. Halina Satkiewicz zwraca uwagę na możliwość przejawiania się agresji w sposób jawny i ukryty (2000: 28). Agresja jawna polega na używaniu słów nacechowanych negatywnie i równocześnie obrażających. Do takich należą niektóre nazwy zwierząt odnoszące się do człowieka, np. „baran”, „osioł”, „świnia”. Ale nie tylko. Agresywne jest nazywanie za pomocą słów o negatywnym zabarwieniu cech, na które człowiek nie ma wpływu, np. nazywanie osoby małego wzrostu „kurduplem”. Oto przykłady agresywnych wypowiedzi:

To by wyjaśniało zagadki kolejnych podbródków K. - poseł tyje, bo zajada stresy nocami („Gazeta Pomorska” 3.10.2014: 30).

(...) zdaniem idiotów, nazywanych w kręgach dyplomatycznych ekologami (,Gazeta Prawna" 10.10.2014: A18).

W pierwszym z przykładów nadawca deprecjonuje osobę, wskazując na jej wygląd. Drugi przykład zawiera silnie nacechowane słowo ,idiota”, poprzez które nadawca deprecjonuje osoby, których przekonań nie podziela.

Agresja jawna może wyrażać się za pomocą intonacji, czyli mówienia podniesionym tonem. W debatach medialnych ten ton często jest stosowany w zwrocie: „Proszę mi nie przerywać!”. Poniższy cytat nie zawiera 
słów nacechowanych negatywnie, ale pochodzi z wypowiedzi, która została wygłoszona podniesionym tonem:

Jakie czynności wykonuje przewodniczący rady i jak wygląda podział pracy między członkami prezydium?

Po odpowiedzi przewodniczącego nadawca kontynuuje:

Bardzo proszę pana przewodniczącego, żeby nie odpowiadał tekstami nie istniejących dokumentów, tylko żeby odpowiadał rzeczowo, co rzeczywiście robi. Bo moim zdaniem głównie usiłuje reprezentować Radę na różnych uroczystościach (z obrad Rady Miejskiej Bydgoszczy w kadencji 1990-1994).

Agresja ukryta nie zawiera słów deprecjonujących, wskazywania na cechy niezależne od osoby deprecjonowanej ani podniesionego tonu. Mimo to zwraca się przeciw osobie. Oto przykład przytoczony przez Sergiusza Kowalskiego:

Otóż Klub Unii Demokratycznej nie jest wcale zdziwiony tym, że pan poseł SS nie może zrozumieć, o co nam chodzi. W imieniu klubu Unii Demokratycznej chciałbym powiedzieć, że całkowicie rozumiemy położenie pana posła SS, który ma kłopoty z percepcją naszych zamierzeń i wystąpień, i wyrazić głęboką nadzieję, że kiedyś będzie nam dane zdumieć się, że pan poseł SS cokolwiek w tej Izbie zrozumie (Kowalski 2001: 85).

Wypowiedź pochodzi z debaty sejmowej. Nadawca wyraża negatywne emocje z powodu braków intelektualnych posła, nazwanego imieniem i nazwiskiem. Wypowiedź deprecjonuje osobę, o której mówi nadawca. W dodatku swoją ocenę nadawca wygłasza w imieniu klubu, do czego prawdopodobnie nie został upoważniony.

Agresja stosowana jest często wobec przeciwnika politycznego, a zarazem nosiciela innej ideologii. Jednakże język agresji i język ideologii nie są tożsame. Cytowane wyżej wypowiedzi nie mają na ogół charakteru ideologicznego.

Czym jest zatem ideologia? Ideologię określa się jako poglądy, idee, pojęcia, założenia; autorzy definicji terminu ideologia zwracają uwagę na uporządkowanie tychże poglądów, idei itp., wskazują na nosicieli ideologii, którymi mogą być jednostki lub grupy, oraz na dziedziny życia, których ideologia dotyczy, jest także mowa o cechach ideologii oraz 
okolicznościach, w których się pojawia9 . Jeden ze współczesnych politologów (Heywood 2008) w następujący sposób rozumie ideologię:

Jest to mniej lub bardziej spójny zbiór idei, stanowiący podstawę zorganizowanego działania politycznego, bez względu na to, czy zmierza ono do zachowania, przekształcenia czy obalenia istniejącego systemu sprawowania władzy. Zatem wszystkie ideologie (a) dostarczają obrazu istniejącego porządku, zazwyczaj w formie obrazu świata, (b) lansują model pożądanej przyszłości, wizję dobrego społeczeństwa, a także (c) wyjaśniają, w jaki sposób zmiana polityczna może się dokonać, czyli jak przejść z (a) do (b) (Heywood 2008: 25).

Nie wchodząc w inne jeszcze propozycje rozumienia ideologii, spróbujmy przyjąć, że ideologia jest zespołem poglądów. Przyjmijmy najpierw szerokie rozumienie określenia zespół poglądów. Takie rozumienie wskazuje na to, że pogląd to sposób widzenia jakiegoś elementu rzeczywistości, który nie daje się bezpośrednio zweryfikować. Niemożność bezpośredniej weryfikacji nie wyklucza jej możliwości, wymaga jednak wielkiego wysiłku. Posłużmy się przykładem: nie ma poglądu na kolor nieba (to da się zweryfikować), ale jest pogląd na istnienie bądź nieistnienie życia poza Ziemią (tego nie da się bezpośrednio zweryfikować). Kiedy treść poglądu zostanie zweryfikowana, będzie to już wiedza, a nie pogląd. W poglądzie zawarty jest element wiedzy i wiary. Każdy człowiek ma wiedzę i zbiór poglądów. Poglądy mogą być w różnym stopniu usystematyzowane. Takie jednak szerokie rozumienie wolałabym zarezerwować dla pojęcia światopogląd. Rozważmy zatem nieco węższe rozumienie określenia ideologia. Propozycja Andrew Heywooda ogranicza ideologię do zbioru przekonań leżących u podstaw działań społeczno-politycznych. Wyznawcy ideologii

${ }^{9}$ Oto wyjaśnienie hasła ,ideologia” w wybranych słownikach:

Słownik wyrazów obcych: ,(gr. idea = idea, wyobrażenie + logos =słowo, nauka). System poglądów, idei, pojęć politycznych, społecznych, prawnych, etycznych, religijnych i filozoficznych jednostki lub grupy w określonym czasie, miejscu i warunkach, zwł. społecznych" (Tokarski 1980).

Słownik współczesnego języka polskiego: „Zespół ściśle określonych założeń i poglądów politycznych, etycznych i filozoficznych, często bezdyskusyjnie przyjmowanych i wcielanych w życie przez określoną grupę ludzi” (Dunaj 2001).

Mała encyklopedia powszechna $P W N$ : „Zbiór poglądów jednostki będący wyrazem jej przeświadczeń i postaw społecznych albo względnie usystematyzowany zbiór poglądów jakiejś grupy społecznej, których funkcją jest orientowanie ludzkiego zbiorowego działania" (Petrozolin-Skowrońska 1997). 
próbują opisać społeczno-polityczny obraz świata, mają jego wizję i starają się ustalić sposób, w jaki dałoby się zmienić obraz rzeczywisty na pożądany. Posłużmy się przykładem. W wieku XIX zaczęła szerzyć się ideologia, którą później nazwano marksizmem-leninizmem, zgodnie z nią obraz społeczno-polityczny ówczesnej rzeczywistości składał się m.in. z prywatnej własności środków produkcji. Prywatna własność była, zdaniem wyznawców ideologii marksistowskiej, przyczyną niesprawiedliwości społecznej, polegającej na krzywdzie proletariatu. Pożądany obraz rzeczywistości społeczno-politycznej wymagał - w świetle omawianej ideologii - odebrania środków produkcji prywatnym właścicielom i ustanowienia społecznej własności środków produkcji. Drogą, która miała doprowadzić do tej zmiany, była rewolucja. Podsumujmy:

- obraz rzeczywisty: prywatna własność środków produkcji;

- obraz postulowany: społeczna własność środków produkcji;

- droga do zmiany: rewolucja.

Na język ideologii składają się zatem:

- wizja świata w postaci diagnozy stanu zastanego;

- wizja świata postulowanego;

- projekt sposobu przekształcenia stanu zastanego w stan postulowany. W diagnozach stanu zastanego pojawiają się nie tylko interpretacje rzeczywistości w postaci aktów asertywnych lub quasi-asertywnych ${ }^{10}$, ale także akty wartościująco-emotywne.

Obserwacja współczesnych wypowiedzi politycznych skłania do stwierdzenia, że najczęściej w dyskursie publicznym pojawiają się diagnozy stanu zastanego. Oto przykłady:

Spektakularnym przykładem łamania w Polsce prawa do sprzeciwu sumienia jest sprawa prof. Bogdana Chazana („Gazeta Polska” 3.10.2014: 5).

Kościołowi i prawicy nie podoba się zastosowana w konwencji definicja płci kulturowej gender (można tu dopisać domyślną formułę: i to źle - przyp. aut.) („Gazeta Wyborcza" 5.12.2014: 6).

Pierwszy przykład stanowi wyrażanie negatywnych emocji wobec łamania prawa do sprzeciwu sumienia, spowodowanego przez przeciwników ideologicznych, stan ten jest niekorzystny dla nadawcy i innych

${ }^{10}$ Aktami quasi-asertywnymi nazywam takie akty mowy, które mają postać konstatacji, ale nie są weryfikowalne, np. „Nie ma ludzi niezastąpionych”. 
nosicieli wyznawanej przez niego ideologii. W drugim przykładzie nadawca wyraża negatywne emocje wobec postawy przeciwników ideologicznych w sprawie konwencji o zwalczaniu przemocy wobec kobiet, postawa ta jest niekorzystna dla nadawcy i jego ideologicznych zwolenników.

W Polsce dominują, jak się zdaje, dwie ideologie. Jedna $\mathrm{z}$ nich nosi wiele cech liberalizmu, dla którego istotne są wolność jednostki i tolerancja (Heywood 2008: 42 i nn.). Druga ideologia ma cechy konserwatyzmu i nacjonalizmu ${ }^{11}$, dla których istotnymi wartościami są tradycja i naród (Heywood 2008: 87, 169 i in.). W związku z tym można mówić o dwóch podtypach dyskursu politycznego: liberalnym i tradycyjno-narodowym ${ }^{12}$. Pojawiają się jednak wypowiedzi nienależące do żadnego z tych dyskursów. Na przykład:

Wszystkie partie tzw. „opozycji” wyśmiewają expose JE Ewy Kopacz - i słusznie. To znaczy: śmieją się słusznie. Natomiast śmieją się nie z tego, z czego powinny („Angora" 12.10.2014: 2).

W dyskursie publicznym przeważa wyrażanie uczuć negatywnych, emocje pozytywne występują znacznie rzadziej. Oto przykład:

Podpisanie przez Polskę konwencji wymusiło zmianę trybu ścigania sprawców gwałtów. Od 1 stycznia tego roku dzieje się to z urzędu, a nie na wniosek ofiary (można dopisać domyślną formułę: i to dobrze) (,Express Bydgoski” 3.10.2014: 11).

Nadawca prezentuje pozytywne emocje wobec działania władz polskich, korzystnych dla ofiar przemocy. Ale i tu, w tle pozytywnie ocenianego faktu, implikowane są negatywne emocje wobec niekorzystnych społecznie zjawisk.

\section{Podsumowanie}

Dyskurs publiczny przesycony jest emocjami. Przeważają emocje negatywne, niekiedy wzmocnione agresją. Motywem do wyrażania emocji

\footnotetext{
${ }^{11}$ Słowo „nacjonalizm” w opracowaniu A. Heywooda nie ma nacechowania negatywnego. Oznacza traktowanie narodu jako głównej organizacji politycznej (cf. Heywood 2008: 169).

${ }^{12}$ Inaczej widzi to J. Bralczyk (1999: 197), który wyróżnia trzy pododmiany języka współczesnej polityki: konserwatywną, narodową i liberalną.
} 
bywa wyznawana ideologia. Nie są to właściwości charakterystyczne wyłącznie dla współczesnego dyskursu publicznego. Irena Kamińska-Szmaj (1994) pokazuje, jak emocje formułowano w języku propagandy politycznej okresu międzywojennego. Emocje w dyskursie publicznym nie są zatem niczym nowym.

\section{Literatura}

Awdiejew A., 2004, Gramatyka interakcji werbalnej, Kraków.

Bralczyk J., 1999, O używaniu języka w polskiej polityce w latach dziewięćdziesiatych, w: Polszczyzna 2000. Orędzie o stanie języka na przetomie tysiącleci, red. W. Pisarek, Kraków, s. 197-217.

Bralczyk J., 2008, Brutalizacja języka publicznego, w: Reverendissimae Halinae Satkiewicz cum magnaaestimatione, red. G. Dąbkowski, Warszawa, s. 59-66.

Cetwiński O., Karwat M., 2001, Polityka jako homeostat systemu społecznego, w: Metafory polityki, red. B. Kaczmarek, Wrocław, s. 17-26.

Dobek-Ostrowska B., 2006, Komunikowanie polityczne i publiczne, Warszawa.

Dunaj B. (red.), 2001, Stownik wspótczesnego języka polskiego, Warszawa.

Heywood A., 2008, Ideologie polityczne. Wprowadzenie, przeł. M. Habura, N. Orłowska, D. Stasiak, Warszawa.

Kamińska-Szmaj I., 1994, Judzi, zohydza, ze czci odziera. Język propagandy politycznej w prasie 1919-1923, Wrocław.

Kamińska-Szmaj I., 2007, Agresja językowa w życiu publicznym, Wrocław.

Kowalski S., 2001, O sejmowej antyetykiecie, w: Zmiany w publicznych zwyczajach językowych, red. J. Bralczyk, K. Mosiołek-Kłosińskiej, Warszawa, s. 85-91.

Laskowska E., 2004, Dyskurs parlamentarny w ujęciu komunikacyjnym, Bydgoszcz.

Laskowska E., 2009a, Nazywanie i wyrażanie uczuć w języku, Zielonogórskie Seminaria Językoznawcze, Zielona Góra, s. 351-361.

Laskowska E., 2009b, Wartościowanie w dyskursie publicznym, w: Problemy komunikacji społecznej, red. G. Habrajska, Łask, s. 55-71.

Peisert M., 2004, Formy i funkcje agresji werbalnej. Próba typologii, Wrocław.

Petrozolin-Skowrońska B. (red.), 1997, Mała encyklopedia powszechna PWN, Warszawa.

Satkiewicz H., 2000, Językowe przejawy agresji w mediach, w: Język w mediach masowych, red. J. Bralczyk, K. Mosiołek-Kłosińska, Warszawa, s. 28-42.

Tokarski J. (red.), 1980, Stownik wyrazów obcych, Warszawa.

Walczak B., 1994, Co to jest język polityki?, w: Język a kultura, t. 11, Język polityki a wspótczesna kultura polityczna, red. J. Anusiewicz, B. Siciński, Wrocław, s. 15-20. 